\title{
ODRAZ REALITY V KONCEPČNÝCH PRÍSTUPOCH VYSVETLUJÚCICH REGIONÁLNY ROZVOJ
}

\section{REALITY IN THE MIRROR OF CONCEPTUAL REGIONAL DEVELOPMENT APPROACHES}

\author{
DOC. ING. JOZEF TVRDOŇ, PHD. \\ Katedra verejnej správy a regionálneho rozvoja $\mid$ Dep. of Public Administration and Reg. Development \\ Národohospodárska fakulta Faculty of National Economy \\ Ekonomická univerzita v Bratislave University of Economicsin Bratislava \\ $\bowtie$ Dolnozemská cesta 1, 85235 Bratislava, Slovak Republic \\ E-mail: jozef.tvrdon@euba.sk
}

\begin{abstract}
Anotácia
Príspevok sa zaoberá teoretickými prístupmi k rozvoju v priestore. Poukazuje na význam teoretických pristupov, ktoré vysvetlovali vývoj v priestore a osobitne poukazuje na vývoj myslenia $v$ druhej polovici 20-eho storočia až po súčasnost'. Vývoj teoretického myslenia hodnotí z hl'adiska vysvetlovania reality $v$ teoretických koncepciách, zaoberajúcimi sa regionálnym rozvojom. Záver príspevku je zameraný na možné smery vývoja koncepčných prístupov vysvetlujúcich regionálny rozvoj.

\section{Kl'účové slová}

rozvoj v priestore, realita $v$ teoretických pristupoch, možné smery myslenia v budúcnosti

\section{Annotation}

The paper presents theoretical approaches toward development of space. It points at the importance of theoretical approaches dealing with spatial development especially the development of the second part of the 20 th century until present. Theoretical development is evaluated from the point of view of reality in theoretical regional development concepts. The final part of the paper is devoted to possible ways of development in theoretical approaches explaining regional development.
\end{abstract}

\section{Key words}

spatial development, reality in theoretical approaches, possible ways of thinking in the future

JEL classification: $R 11$

\section{Úvod}

Regionálna ekonómia je oproti ostatným vedným odborom v ekonomike relatívne mladšou vednou disciplínou. Možno konštatovat', že od vzniku regionálnej vedy v pät'desiatych rokoch minulého storočia vzniklo množstvo teoretických prístupov vysvetl'ujúcich vývoj v priestore ${ }^{1}$, ktoré boli uplatnené pri riešení praktických problémov voblasti regionálneho rozvoja. Vzniklo množstvo teoretických a metodologických prístupov, na základe ktorého bol vývoj v priestore začlenený do logických schém, ktoré regulujú a interpretujú jednotlivé stránky reprodukčného procesu v dynamicky sa rozvíjajúcom priestore. Vznikli teoretické prístupy a zákony, ktoré vysvetl'ujú v trhovej ekonomike vplyv dopytu, cien, výrobných kapacít, úroveň výstupov a ich vplyv na úroveň a dynamiku rastu príjmov v podmienkach nerovnakých zdrojov na rozvoj v priestore.

\footnotetext{
1 Pojem „priestor“ používane ako objekt skúmania vjeho najvšeobecnejšej podobe pre vyjadrenie prebiehajúcich ekonomických javov a procesov. Pritom jeho rozvoj skúmame v rámci regionálnej ekonómie, ktorú pokladáme za jeden z odborov regionálnej vedy.
} 
I ked' sme upozornili na význam regionálnej vedy a jej viac ako polstoročnú existenciu je z hladiska objektivity potrebné poukázat' na teoretické prístupy, ktoré vysvetl'ovali vývoj v priestore a ktoré vznikli v druhej polovici 19-eho storočia a prvej polovici 20-eho storočia.

Značný rozsah poznatkov, ktoré umožnili pochopenie súčasných interakcií medzi jednotlivými aktérmi priestorovej štruktúry poskytuje teória lokalizácie firmy (von Thunen, A. Weber, Launhardt, A. Losch, Christaller - nemecká škola). Teoretické východiská i pre súčasné chápanie základných interakcií medzi priestorom a správaním sa ekonomických subjektov pochádza z oblasti teórie lokalizácie. Teória lokalizácie dáva regionálnej ekonómie svoju vedecko-disciplinárnu identitu a predstavuje jej teoreticko-metodologický základ. Zaoberá sa možnost’ou umiestňovania firiem a domácností. S tým je spojené množstvo teoretických vstupov (z makroekonómie, medziregionálnej teórie obchodu, teórie rozvoja, matematická ekológia, teórie systémov), ktoré poskytli svoje nástroje regionálnej ekonómii, ktorá tak mohla rozvinút' rozsah svojho skúmania. Z mikroekonomického hladiska sa teória lokalizácie zaoberá skúmaním lokalizácie firiem a domácností; ale tiež sa zaoberá analýzou rozdielov v priestorovom rozložení ekonomických činností (vznik nerovnováhy v priestorovom usporiadaní, vznik hierarchie v rámci sídelných systémov). Teória lokalizácie využíva existenciu externalít a vznik aglomerácií k objasneniu takého makroekonomického fenoménu ako sú rozdiely v priestorovom rozložení aktivít a týmto vytvára teoretický základ pre použitie dynamických prístupov.

Ako sme uviedli regionálna veda je pomerne mladá vedná disciplína, ktorej výsledky sú obsiahnuté v množstve teórií, modelov a prístupov, ktorých snahou bolo poskytnút' relatívne komplexný teoretický a metodologický nástroj pre analýzu a tým i riešenie praktických problémov v priestore. Obzvlášt' silná diskusia vznikla $\mathrm{v}$ devät'desiatych rokoch minulého storočia, ktorá bola zameraná na určitú reflexiu a hodnotenie dosiahnutých výsledkov, ktoré dosiahla regionálna veda v uplynulom období jednak z hl'adiska dosiahnutých ciel'ov a boli tiež identifikované nové ciele, ktoré boli adresované regionálnej vede (Bailly, 1992; Bailly and Coffey, 1994; Funck, 1991; Isserman, 1993, 1995; van Geenhuizen and Nijkamp, 1996). Dôsledok tejto diskusie prispel k posilneniu a vytvoreniu nových teoretických a metodologických nástrojov. Súvisí to i so zvýšeným záujmom o priestor najmä po kríze v 80-tych rokoch, kedy v rámci všeobecnej ekonomickej teórie prevládal teoretický prístup založený na neoklasickej teórii.

Význam potreby skúmania priestoru v devät'desiatych rokoch i v súčasnosti rastie. Dôvodom je zvýšený záujem tvorcov politiky o staré ako aj nové regionálne a priestorové problémy. Staré problémy, ako sú regionálne disparity (rozdiely), sa prehlbujú v rámci Európskej únie po vstupe nových členov, ktorých výkonnost' ekonomiky ako celku je nižšia, existujú výrazné rozdiely v ekonomickej úrovni regiónov, ktoré dosahujú nižšiu ekonomickú úroveň, ako je priemer Európskej $u^{n} i^{2}$. Nové problémy a stanovené princípy ako je územná súdržnost' - predstavujú nové normatívne prístupy $\mathrm{v}$ rámci EÚ, ktoré sú uvedené $\mathrm{v}$ oficiálnych dokumentoch EÚ a sú $\mathrm{v}$ súlade $\mathrm{s}$ ostatnými princípmi Lisabonskej zmluvy (Luxemburské predsedníctvo, 2005a a 2005b) ${ }^{3}$. V tejto súvislosti stojí pred tvorcami teórie i politiky poskytnút' také teoretické i metodologické nástroje na ktoré sa normatívne rozhodnutia môžu spol'ahnút'.

Ďalším dôvodom, prečo je potrebné v súčasnosti rozvíjat' regionálnu vedu je potreba jej širšieho prepojenia shlavnými teoretickými prúdmi všeobecnej ekonomickej teórie. Toto prepojenie v súčasnosti je nedostatočné i ked' sme si vedomí toho, že každá teória predstavuje model, ktorý do určitej miery využíva metódu abstrakcie, v rámci ktorej abstrahuje od „menej významných faktorov“, vplývajúcich na skúmaný objekt. A práve vplyv faktorov ovplyvňujúcich rozvoj v priestore (potenciál, možnosti vytvárania produkčných sietí, klastrov a pod.) môže komplikovat’ závery teórie v hlavnom ekonomickom smere.

\footnotetext{
${ }^{2}$ Prejavilo sa to po vstupe tzv. kohéznych krajín - Španielska, Portugalska, Írska a Grécka do EÚ. Ďalej po rozsiahlom rozšírení EÚ v máji 2004 - rozšírenie prinieslo 5\% zvýšenie HDP EÚ, zvýšenie o 20\% obyvatel’ov; v dôsledku čoho pokleslo HDP na obyvatel'a v EU o 12,5\% v deň rozšírenia. Podobný efekt nastal i po vstupe Bulharska a Rumunska do EÚ.

${ }^{3}$ „Z praktického hl’adiska územná súdržnost' znamená: zameranie regionálnej a národnej ekonomiky územného rozvoja na lepšie využívanie regionálnych potenciálov a územného kapitálu...“.
} 


\section{Zmeny pohl'adu na úlohu priestoru}

V histórii regionálnej ekonómie môžeme pozorovat' rozdielne postavenie a úlohu priestoru. $\mathrm{V}$ pôvodných teoretických úvahách priestor vystupuje $\mathrm{v}$ podobe fyzickej bariéry oproti ekonomickým činnostiam v ňom lokalizovaným. Berie do úvahy fyzické vzdialenosti medzi vstupnými a výstupnými trhmi v podobe dopravných nákladov. Teórie, ktoré vznikli v pät'desiatych a šest'desiatych rokoch minulého storočia používali priestor ako abstraktnú jednotku, ktorá bola rozčlenená do regiónov, ktoré spravidla zodpovedali správnym jednotkám a ktoré boli vnútorne jednotné z hl'adiska ich sociálno ekonomických charakteristík. Výhodou tohto poňatia priestoru je, že umožňuje využitie makroekonomických modelov na vysvetlenie fenoménu regionálneho rastu. V oboch prípadoch nezohrával priestor žiadnu úlohu v určovaní cesty vývoja lokálnej ekonomiky.

Radikálna zmena vpohlade na úlohu priestoru prebehla $\mathrm{v}$ sedemdesiatich rokoch. Priestor bol koncipovaný ako ekonomický zdroj, ako samostatný výrobný faktor. Stal sa generátorom statických a dynamických výhod pre firmy a klúčovým faktorom konkurencieschopnosti miestneho výrobného systému. Podl'a teórií regionálneho rozvoja, priestor bol zdrojom rastúcich výnosov a pozitívnych externalít, ktoré predstavujú spoločné aglomerácie a v ňom lokalizované faktory rozvoja. Vyššie tempo rastu bolo dosiahnuté v miestnych výrobných systémoch, kde rastúce výnosy fungujú podl'a miestnej produktivity, znižujú výrobné a transakčné náklady, čo vedie k zvýšeniu efektivity výrobných faktorov a zvýšeniu inovačnej kapacity. Regionálny rozvoj závisí od efektívnosti koncentrovanej územnej organizácie výroby, nie na dostupnosti hospodárskych zdrojov alebo na ich účinnejšom priestorovom usporiadaní. Priestor sa zmenil na diverzifikovano-vzt'ahový priestor. Diverzifikovatel'nost' priestoru je $\mathrm{v}$ tom, že je l'ahko rozlíšitel'ná (aj vnútorne v regióne) i nevyváženost' rozdelenia jednotlivých činností. Vývoj prichádza selektívne v oblastiach, kde koncentrovaná organizácia výroby uplatňuje svoj pozitívny vplyv na parametre statickej a dynamickej efektívnosti. V rovnakom čase, priestor je vzt’ahový, v tom, že hospodárske a sociálne vzt’ahy vznikajú voblasti vykonávania klúčových funkcií. Zaist'ujú plynulejšiu realizáciu trhového mechanizmu, vzniká a medzi jednotlivými aktérmi sa šíri viac efektívnosti a menej výrobných nákladových procesov, akumulujú sa znalosti miestneho trhu a zrýchl'uje sa tempo inovácií - a to sú všetko faktory, ktoré podporujú miestny rozvoj.

Začlenenie aglomeračných efektov - v podobe rastúcich výnosov - do modelu čisto makroekonomickej povahy, bolo umožnené pokrokom v matematických nástrojoch pre analyzovanie kvalitatívneho správania sa dynamického nelineárneho systému (rozdvojenia, katastrofy a teórie chaosu) spolu s príchodom formalizovaných ekonomických modelov, ktoré opustili hypotézy konštantných výnosov a dokonalej konkurencie. Tieto nové pokrokové teórie si vyžadujú nové definovanie pojmu priestoru a to diverzifikovane - štylizovaný priestor. Priestor v týchto nových teóriách regionálneho rastu rozlišuje úroveň rýchlosti rastu príjmov aj medzi oblast’ami v rámci regiónu. Tento prístup sa odlišuje od koncepcií jednotného - abstraktného priestoru, vysvetl'ovaného $\mathrm{v}$ teóriách regionálneho rastu $\mathrm{v}$ pät'desiatich a šest'desiatich rokoch, ktorý bol jednotný v podmienkach ponuky (odvetvová a výrobná štruktúra) a v podmienkach dopytu (Capello, 2007).

Za účelom posilnenia úlohy priestoru $\mathrm{v}$ inovačných aktivitách, teórie regionálneho rastu zmenili svoj pohl'ad na priestor ako čistý generátor statických výhod a sústredili svoju pozornost' na úlohu priestoru pri vytváraní znalostí a z toho prameniacu dynamiku aglomeračných efektov.

V súčasných teóriách regionálneho rastu priestor sa chápe ako „kognitívny priestor“, ktorý je schopný využit' informácie za účelom identifikovania a riešenia problémov, alebo práve v ekonomickej oblasti má schopnost' premenit' informácie a poznatky do inovácií a rastu produktivity. V tomto chápaní má význam i kooperácia medzi miestnymi aktérmi. Priestor znižuje neistotu, informačné asymetrie (a teda aj vzájomné podozrievanie medzi partnermi) a pravdepodobnosti oportunistického správania pod hrozbou sociálnych sankcií (Camagni, 1991 a 2004). V dôsledku kognitívnej blízkosti priestor obsahuje vel’a prvkov, ktoré sú potvrdené mnohými regionálnymi ekonomickými školami (Bellet et al. 1999; Rallet a Torre, 1995; Cappellin, 2003a): prijaté kódexy správania, spoločná kultúra, vzájomná 
dôvera a zmysel pre vysvetlovanie procesu vytvárania vedomostí a procesov kolektívneho učenia sa. V kontexte vyznačujúcou sa rozmanitost'ou sprostredkovatel'ov (ako napríklad v priemyselných oblastiach a výrobných klástroch) šírenie znalostí „nie je výsledkom individuálnych snáh v oblasti výskumu a vývoja vrámci jednotlivých firiem, ale skôr kombinácie doplnkových kapacít a rozsiahlych interaktívnych vzdelávacích procesov, ktoré zahŕñajú mnoho „zákazníkov“ a „dodávatel'ov“" po presne vymedzených dcérskych spoločností alebo dodávatel'ského ret’azca“ (Cappellin, 2003b, s. 307).

Pojem priestor sa stáva $\mathrm{v}$ týchto prístupoch reálnym priestorom, kde funkčné a hierarchické, ekonomické a sociálne procesy prebiehajú a sú vložené do geografického priestoru v ktorom dochádza k rastu spolupráce, procesov učenia, ktoré sú lokálne vyvinuté, živené priestorovou blízkostou (,atmosféra“, efekty), siet'ových vzt'ahov, interakcií, tvorivost'ou a schopnost'ou vytvárat' nové kombinácie vzt’ahov (Camagni a Capello, 2006).

\section{Konvergencia a divergencia $\mathrm{v}$ priestore}

Druhou oblast’ou, ktorá v rámci uvedenej diskusie bola označená, že sa jej nevenovala dostatočná pozornost' $\mathrm{v}$ existujúcich teoretických prístupoch bola potreba obrátenia pozornosti na praktické problémy. Do pozornosti teórie sa dostávajú niektoré staré regionálne problémy. Jedným z týchto problémov je diskusia o konvergencii, resp. divergencii a prístupu jednotlivých teórií $\mathrm{k}$ ich vysvetleniu.

Diskusia o konvergencii resp. divergencii bola vyvolaná ako dôsledok rozšírenia EÚ o nové členské krajiny. Z teoretického hladiska, bol rozhodujúci pokrok dosiahnutý v tejto oblasti a tradičný rozdiel často opisovaný $\mathrm{v}$ učebniciach regionálnej ekonómie - medzi teóriou konvergencie a divergencie je $\mathrm{v}$ tom, že skúmajú dôvody znižovania/zvyšovania rozdielov medzi bohatými a zaostalými regiónmi.

Na konvergenčnej strane sú teórie pochádzajúce z neoklasických východísk a ktoré vysvetlujú (vo svojej počiatočnej formulácii) rozvoj ako proces inklinovania k rovnováhe $\mathrm{z}$ dôvodu vplyvu trhových síl. V rovnováhe nie je len optimálna alokácia zdrojov ale aj rovnaká distribúcia výrobných faktorov $\mathrm{v}$ priestore, ktoré zaručujú tendenciu k vyrovnávaniu úrovne rozvoja medzi regiónmi.

$\mathrm{Na}$ strane divergencie stoja teórie keynesiánskeho pôvodu, ktoré tým, že zavádzajú pozitívne a negatívne mechanizmy spätnej väzby a kumulatívne pritahovanie a odčerpávanie zdrojov do rozvinutých regiónov, predpokladajú nielen zotrvačnost', ale aj zhoršenie nerovností medzi regiónmi (Myrdal - teória kumulatívnych príčin).

Možno uviest', že určitý druh zaujatosti sprevádza diskusie o rozdieloch medzi divergenčnými a konvergenčnými teóriami v dejinách regionálnej ekonómie. V šest'desiatich rokoch, Borts a Stein vytvorili model (známy ako dvoj regionálny - dvoj sektorový model), v ktorom poukázali na to, že ak dva regióny začínajú na rovnakej úrovni, a jeden rastie viac ako druhý pre externé vplyvy, je tendencia k prehlbovaniu regionálnych rozdielov. Dôvod je nasledovný: príjmy vytvorené v regióne na základe vyvezených výrobkov sa líšia od disponibilných príjmov v sume, ktorá sa rovná odmene z požičaného kapitálu. Vnútorné úspory, vypočítané ako podiel disponibilného príjmu, preto nikdy nebudú dostatočným zdrojom financovania miestnej produkcie. Nedostatok kapitálu zaručuje vysokú odmenu tohto výrobného faktora (práce) a to vedie ku stálemu prílevu kapitálu z vonku. V dôsledku toho regionálna miera rastu $\mathrm{v}$ tomto regióne je trvalo vy̌šsia ako u ostatných regiónoch. Tok pracovníkov do exportného regiónu mení pomer kapitálu ku pracovnej sile a tým zmierňuje rozdiely $\mathrm{v}$ mierach rastu.

V posledných rokoch, pokročilé matematické a modelové nástroje ukázali, že rovnaké teórie sú schopné vysvetlit' ako procesy divergencie, tak aj konvergencie. Napríklad, zahrnutie vel'kosti ekonomiky a aglomeračných efektov do produkčnej funkcie (viac komplexne ako to bolo v modeloch v roku 1960), neoklasický model úspešne napodobňuje rad správaní a tendencií, a to ako kontinuálne prebiehajúce, tak aj „katastrofálne“ a sú v značnej miere vzdialené od mechanických 
a jednovýznamových konvergenčných predpovedí pôvodného neoklasického modelu. Rovnakým spôsobom rozdiely vyplývajúce $\mathrm{z}$ keynesiánskych modelov (najmä podl'a Myrdala a Kaldora) vyvolávajú otázky či dynamické rovnice popisujú ekonomickú logiku modelu, miestny systém bud' konverguje pri neustálom raste alebo sa odchyluje od neho.

Je teda možné konštatovat', že pominuli dôvody pre akékol'vek dychotómie, ktoré majú byt' rozlišované medzi teóriou konvergencie a divergencie, medzi teóriami optimistickými a pesimistickými. Avšak, problém sám o sebe je stále prítomný a to v ovel’a väčšej miere ako v minulosti. Neoklasický model, elegantný vo svojej formulácii a konzistentnosti vo svojej ekonomickej logike, bol často kritizovaný ako nevhodný (v jeho pôvodnej formulácii) vo výklade stálych a pretrvávajúcich regionálnych rozdielov. Naopak Keynesiánskemu modelu bolo vyčítané, že nie je schopný predvídat' územné limity vývoja kumulatívneho procesu, aj ked' tieto limity majú významný vplyv na rozvoj regiónu. Ale ak „teórie divergencie/konvergencie“ dychotómiu opustia, navrátia vypovedaciu schopnost' každému prístupu a tým umožnia využívat' široký rad koncepčných nástrojov, pomocou ktorých sa dajú interpretovat' zložité procesy rozvoja v priestore.

\section{Odraz reality v koncepčných prístupoch, vysvetl'ujúcich regionálny rozvoj}

Väčšia potreba realizmu $\mathrm{v}$ teóriách vysvetlujúcich regionálny rozvoj vyplýva z potreby zachytit' procesy vo vnútri regiónu, ktoré majú nelineárny charakter, zachytit'interaktívne správanie sa všetkých aktérov, ako i procesy vysvetl'ujúce regionálnu konkurencieschopnost' v kontexte endogénnych faktorov. Otázka, či je región schopný rozvoja na základe endogénnych faktorov je diskutovaný desat'ročia. Spravidla ide o princípy ako: rozvoj regionálnych zdrojov (podnikanie, veda, kvalifikácia), modernizácia existujúcich podnikov, rozvoj energetických a environmentálnych projektov, vnútroregionálna dopravná vybavenost', konkurenčná schopnost' prostredníctvom kvality produkcie a inovácií, široká účast' regionálnych záujmových skupín a pod (Maier, G., Todtling, F.,1998) .

Významným teoretickým prínosom v tejto oblasti je zameranie na úspory z rozsahu, ktoré spolu s nelineárnymi nákladmi na dopravu, sú zahrnuté do rastového modelu (Krugman, 1991). Dodatočný prínos Krugmana spočíva $\mathrm{v}$ zahrnutí modelovaného vzájomného pôsobenia medzi prepravnými nákladmi a úsporami z rozsahu v oblasti výroby.

Ďalším príspevkom v rozvoji endogénnych regionálnych teórií je vel'ký dôraz kladený na znalosti ako hnaciu silu rozvoja. Úplne novým pohl'adom je dôraz na samoposilňovacie mechanizmy vytvárania znalostí. V nových teóriách rastu (presnejšie $\mathrm{v}$ endogénnych teóriách) technologický pokrok je exogénnou reakciou hospodárskych subjektov v konkurenčnom prostredí. Presnejšie povedané, rastúce výnosy v produktivite prameniace $\mathrm{z}$ endogénnych faktorov - ako sú inovácie, úspory z rozsahu a proces vzdelávania - sú zahrnuté v neoklasickej produkčnej funkcii, kde vyrovnávajú účinok marginálnej produktivity jednotlivých faktorov.

\section{Záver}

Ked' máme zhrnút' vyššie uvedené teoretické poznatky vysvetlujúce rozvoj v priestore, ako i teoretické prístupy odrážajúce reálne procesy v regionálnej ekonomike, možno uviest', že vývoj je $\mathrm{v}$ skutočnosti $\mathrm{v}$ rozhodujúcej miere endogénny. Je v podstate závislý na koncentrácii usporiadania aktérov, do ktorého je vložený socio-ekonomický a kultúrny systém, od ktorých závisí stupeň rozvoja regionálnej ekonomiky. Ide o podnikatel'ské schopnosti, miestne výrobné faktory (práca a kapitál), vzájomné zručnosti miestnych aktérov generujúcich kumulatívne získavanie poznatkov, rozhodovacie schopnosti, ktoré umožňujú miestnej ekonomike a sociálnym aktérom vplývat' na rozvojový proces, podporit' ho, ked' prechádza procesom zmien a inovácií a obohatit' ho o externé informácie a znalosti potrebné na premeny regionálnej ekonomiky. 
Dynamiku rastúcich výnosov možno definovat' ako výhody, ktoré pôsobia na kapacitu firiem a regióny nabádajú $\mathrm{k}$ inováciám, stávajú sa centrom súčasných teórií, čo vedie $\mathrm{k}$ neoSchumpeterovským prístupom v regionálnom rozvoji, sciel'om identifikovat' úlohu priestoru $\mathrm{v}$ inovačných procesoch.

Endogénne faktory vplývajúce na vznik a šírenie znalostí predstavujú prínosy v podobe dynamických výhod plynúcich z:

- priestorovej blízkosti medzi firmami, ktorá ulahčuje výmenu vedomostí, ide o koncentráciu inovačných činností;

- blízkosti medzi firmami, definovaných ako vzájomné vzt’ahy spolupráce medzi miestnymi agentmi, zdrojom kolektívneho procesu vzdelávania a socializácie (t.j. územných vzt’ahov medzi subjektmi pôsobiacimi v geografickej a sociálnej blízkosti),

- inštitucionálnej blízkosti, ktorá formuje pravidlá, predpisy a normy správania, ktoré ul’ahčujú spoluprácu medzi aktérmi a preto socializácia vedomostí pomáha hospodárskym aktérom (fyzické osoby, firmy a miestne inštitúcie) rozvíjat' organizačné formy, ktoré podporujú interaktívne vzdelávacie procesy a tým podporujú vznik inovačných systémov v priestore.

\section{Literatúra}

[1] ARMSTRONG, H., TAYLOR, J. Regional Economics and Policy. Blackwell Publishing. Great Britain, 1993.

[2] BUČEK, M., REHÁK, Š., TVRDOŇ, J. Regionálna ekonómia a politika, Bratislava: Iura Edition, 2010.

[3] CAPELLO, R. Regional Economics, London: Routledge, 2007. 319 p. ISBN 978-0-415-395205.

[4] CAPELLO, R. Recent theoretical directions and future challenges in regional economics, In 3rd Central European Conference in Regional Science - CERS, 2009.

[5] GORZELAK, G., KUKLIŃSKI, A. Dilemmas of Regional Policie in Eastern and Central Europe. Warszsawa: Institute of Space Economy, 1992.

[6] HALKIER, HENRIK. Governance, Institutions and Regional Policy: Trends and Chal-lenges in Western Europe, Keynote, SIRIUS Autumn School, EPRC, Strathclyde University, Glasgow, Storbritannien, 2002.

[7] KLAASSEN, L.H., VANHOVE, N. Regionální politika: európsky prístup (preklad - Regional Policy: A European Approach). Ostrava: VUROM, 1990.

[8] MAIER, G., TODTLING, F. Regionálna a urbanistická ekonomika 2. Bratislava: Elita, 1998. ISBN 80-8044-044-1.

[9] PORTER, M. E. The Competitive Advantage of Nations. New York: The Free Press, 1990. ISBN 0-02-925361-6.

[10] SCOTT, A., STORPER, M. Regions, Globalization, Development. Regional studies, 2007, Volume 41, 40th Anniversary Classic Papers Suplement. ISSN 0034-3404.

[11] TVRDOŇ, J. Regionálny rozvoj - teoretické východiská, In Regionálna diferenciácia, regionálny rozvoj v Slovenskej republike v kontexte integračných dosahov, Sociologický ústav SAV, Bratislava 2006, str. 400 - 438, [CD/ROM]. ISBN 80-85544-38-5.

Príspevok bol spracovaný v rámci riešenia projektu KEGA č. 009EU - 4/2011 „Inovácia obsahu vzdelávania vo verejnej správe a nadväzná tvorba modernej vysokoškolskej učebnice“. 